\title{
An Experimental Investigation on the Effects of Concrete by Replacing Cement with GGBS and Rice Husk Ash with the Addition of Steel Fibers
}

\author{
Roopa Saira Thomas ${ }^{1}$, Jebitta Fancy Rajaselvi .P² \\ ${ }^{1}$ M.E structural engineering student, JCT College of Engineering and Technology, Coimbatore, Tamil Nadu, India \\ ${ }^{2}$ Asst. Professor, Civil department, JCT College of Engineering and Technology, Coimbatore, Tamil Nadu, India
}

\begin{abstract}
There has been a tremendous increase in the use of mineral admixture by industries during the late 20th century and the rate is expected to increase. Concrete is an artificial material, which is made up of cement, fine aggregates, coarse aggregates and water. The increasing demand for cement and concrete is met by the partial cement replacement by addition of supplementary cementing materials which leads to several improvements in the concrete composites and to the overall economy. Mineral admixtures are used in concrete because they improve the properties of concrete. The lower cement content leads to a reduction for $\mathrm{CO}_{2}$ generated by the production of Portland cement. An attempt is made to replace the cement with GGBS with $20 \%, 30 \% 40 \%$ and RHA and steel fiber by constant proportion(10\% and 1\%) for minimum grade concrete i.e., M30 and is tested for fresh and hardened properties at 7,14 and 28 days to identify the optimum percentage of GGBS in concrete. Replacement of cement by GGBS in M30 grade concrete in compressive strength split tensile test and flexural strength improvement up to the replacement of $30 \%$ in all ages.
\end{abstract}

Keywords: GGBS, RHA, steel fibers, compressive strength, tensile strength and flexural strength

\section{Introduction}

Concrete has been the major instrument for making steady and reliable infrastructure since the days of Greek and roman civilization. Concrete is the most world widely used construction material. Concrete is a blend of cement, water, and aggregates with or without chemical admixtures. The most important part of concrete is the cement. Use of cement alone as a binder material produces large heat of hydration. Since the production of this raw material produces lot of $\mathrm{CO}_{2}$ emission. The $\mathrm{CO}_{2}$ emission from the cement source is very harmful to the environmental changes. Nowadays many experiments have been carried out to reduce the $\mathrm{CO}_{2}$. The productive way of minimizing $\mathrm{CO}_{2}$ emission from the cement industry is to use the industrial by products or use of supplementary cementing material such as Ground Granulated Blast Furnace Slag (GGBS), Fly Ash (FA), and Metakaolin (MK). In this present experimental work an attempt is made to replace cement by GGBS and RHA by constant proportion with the addition of steel fibers to overcome these problems.

\subsection{Ground Granulated Blast Furnace Slag(GGBS)}

Ground Granulated Blast Furnace is a byproduct from the Blast furnace slag is a solid waste discharged in large quantities by the iron and steel industry in India. These works at a temperature of about 1500 degree centigrade and are fed with a carefully regulated mixture of iron. The parent rock is reduced to iron and remaining materials from slag that floats on top of the iron. This slag is regularly tapped off as a molten liquid and if it is to be used for the manufacture of GGBS it has been rapidly quenched in large volumes of water. The quenching optimizes the cementitious properties and produces flakes similar to coarse sand. This granulated slag is then dried and ground to a fine powder. The main ingredient of slag is lime $(\mathrm{CaO})$ and silica $(\mathrm{SiO} 2)$. Portland cement also contains these constituents. The principal constituent of slag is soluble in water and shows an alkalinity like that of cement or concrete.

\subsection{Rice Husk Ash (RHA)}

Rice husk is an agricultural residue consisting of noncrystalline silicon dioxide with high surface area and high pozzolanic reactivity, thus due to increasing environmental concern and the need to protect energy and resources, utilization of industrial and biogenic waste as supplement material has become an essential part of concrete construction. Pozzolonas improve strength because they are small in size when compared to the cement particles, and can pack in between the cement particles and provide a superior pore structure. RHA has two roles in concrete manufacture, as a substitute for Portland cement, reducing the cost of concrete in the manufacturing of low priced building blocks, and as an admixture in the production of high strength concrete.

\subsection{Objective}

1. To study the mechanical properties such as compressive strength, split tensile strength and flexural strength of the specimen.

2. To compare the results of different tests with varying proportions of GGBS $(20 \%, 30 \%$ and $40 \%)$ keeping RHA and steel fiber content constant $(10 \%$ and $1 \%)$.

3. To find the optimum percentage of replacement of cement with GGBS.

4. To find the effects of GGBS and RHA on concrete with addition of steel fibres. 


\section{International Journal of Science and Research (IJSR)}

ISSN (Online): 2319-7064

Index Copernicus Value (2013): 6.14 $\mid$ Impact Factor (2014): 5.611

\section{Materials and Methods}

\subsection{Cement}

Ordinary Portland cement of 53 grade (Dalmia) conforming to IS $12269-1987$ is being used. Table I shows the test results.

Table 1: Properties of Cement

\begin{tabular}{|c|c|}
\hline Properties & Cement \\
\hline Specific gravity & 3.1 \\
\hline Standard Consistency & $31 \%$ \\
\hline Initial setting time & $44 \mathrm{~min}$ \\
\hline Final setting time & $480 \mathrm{~min}$ \\
\hline Finess & 4.33 \\
\hline
\end{tabular}

\subsection{Fine aggregate}

Natural river sand of size below $4.75 \mathrm{~mm}$ according to zone II of IS 383-1970 is used as fine aggregate. Table 2 shows the test done on basic properties of fine aggregates.

Table 2: Properties of fine aggregate

\begin{tabular}{|c|c|}
\hline Properties & Fine Aggregate \\
\hline Specific Gravity & 2.72 \\
\hline Fineness modulus & 4.92 \\
\hline
\end{tabular}

\subsection{Coarse Aggregate}

Natural crushed stone with $20 \mathrm{~mm}$ size is used as coarse aggregate. Table 3 shows the test results of properties.

Table 3: Properties Coarse aggregates

\begin{tabular}{|c|c|}
\hline Properties & Coarse Aggregate \\
\hline Specific Gravity & 2.74 \\
\hline Fineness modulus & 3.57 \\
\hline
\end{tabular}

\subsection{Ground Granulated Blast Furnace Slag}

GGBS was collected from AASTRA chemicals, Chennai. Table 4 shows the test results of basic properties of GGBS.

Table 4: Properties of GGBS

\begin{tabular}{|c|c|}
\hline Characteristics & Test result \\
\hline Fineness ( M / Kg) & 390 \\
\hline Specific Gravity & 2.85 \\
\hline Particle Size ( Cumulative \% ) & 97.10 \\
\hline Insoluble Residue ( \% ) & 0.49 \\
\hline
\end{tabular}

\subsection{Rice Husk Ash}

RHA was collected from Keerthi Rice Mill from Palakad dist, Kerala. The following property of RHA is shown below in the table 5.

Table 5: Properties of RHA

\begin{tabular}{|c|c|}
\hline Particulars & Properties \\
\hline Color & Gray \\
\hline Particle size & $<45$ micron \\
\hline Specific Gravity & 2.3 \\
\hline Appearance & Very fine \\
\hline
\end{tabular}

\subsection{Steel Fibers}

Steel fibers are not a substitution to reinforcement or aggregate. These are added to increase the flexural strength of concrete. Hooked end steel fibers are used.

Table 6: Properties of Steel fibers

\begin{tabular}{|c|c|}
\hline Particulars & Properties \\
\hline Type & Hooked End \\
\hline Appearance & Clear and Bright \\
\hline Length & $50 \mathrm{~mm}$ \\
\hline Diameter & $1 \mathrm{~mm}$ \\
\hline Aspect Ratio & 50 \\
\hline
\end{tabular}

\subsection{Water}

Ordinary portable water is used in this investigation both for mixing and curing.

\subsection{Super Plasticizer (SP)}

GLENIUM 51 is used as a superplasticizer. It is a chloride free, super plasticizing admixture. It was used to intensify the workability of concrete

Table 7: Properties of SP

\begin{tabular}{|c|c|}
\hline Particulars & Properties \\
\hline Appearance & Light Brown Liquid \\
\hline $\mathrm{pH}$ & $>=6$ \\
\hline Specific Gravity & 50 \\
\hline
\end{tabular}

\subsection{Concrete Mix Design}

Mix proportion used in this study is 1:1.61:2.65 (M30) with water-cement ratio of 0.4 and super plasticizer of $0.75 \%$.

\section{Results and Discussions}

\subsection{Compressive Strength Results}

The cubes of $150 \times 150 \times 150 \mathrm{~mm}$ sizes are casted with various proportions. The test was carried at the end of 7 days, 14 days and 28 days of curing. The compressive strength of any mix was taken as the average of strength of three cubes.

Table 8: Compressive strength Results

\begin{tabular}{|c|c|c|c|}
\hline $\begin{array}{c}\text { Mix } \\
\text { Proportion }\end{array}$ & 7 Days & 14 Days & 28 Days \\
\hline $\begin{array}{c}\text { Normal } \\
\text { concrete }\end{array}$ & 24.67 & 30.37 & 37.96 \\
\hline BC1 & 26.59 & 32.74 & 40.92 \\
\hline BC2 & 28.21 & 34.72 & 43.40 \\
\hline BC3 & 27.20 & 33.48 & 41.85 \\
\hline
\end{tabular}

Note: BC1-20\%GGBS, BC2- 30\%GGBS, BC3- 40\%GGBS

The compressive strength of concrete with replacement of cement by GGBS of $20 \%, 30 \%$ and $40 \%$ keeping the proportion of RHA $(10 \%)$ and steel fiber $(1 \%)$ constant is shown. The test results show that the compressive strength increases as the percentage of slag increases. The strength was found to be increased up to $30 \%$ of GGBS and when above $30 \%$ replacement, there exceeded was a marginal 


\section{International Journal of Science and Research (IJSR) \\ ISSN (Online): 2319-7064}

Index Copernicus Value (2013): 6.14 | Impact Factor (2014): 5.611

decrease in strength of concrete. For 28 days curing period, the strength of concrete increased about $7.79 \%$ and $14.33 \%$ for $20 \%$ and $30 \%$ and decreased about $20.24 \%$ for $40 \%$.

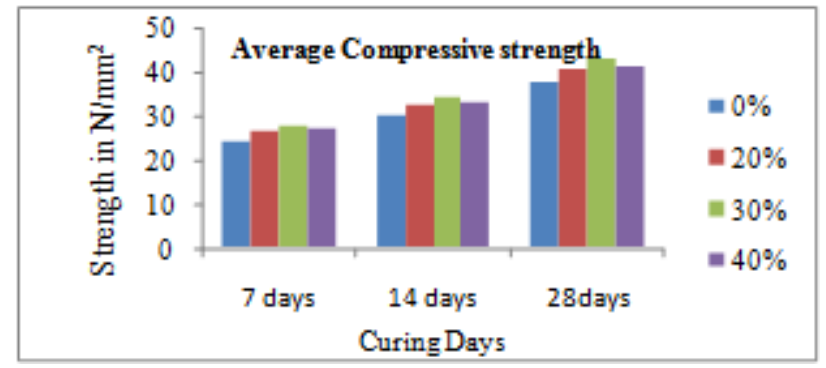

Figure 1: Compressive Strength

\subsection{Split Tensile Strength}

The split tensile strength is the indirect measurement to determine the strength of concrete. Cylinders of size $150 \mathrm{~mm}$ diameter and $300 \mathrm{~mm}$ in length were casted for various percentages of GGBS. The test results shows that there is an increase in the strength only up to $30 \%$ slag and beyond $30 \%$ the strength showed no change in increase and it was also observed that the strength showed increased only after 28 days of curing period.

Table 9: Split Tensile strength results

\begin{tabular}{|c|c|c|c|}
\hline $\begin{array}{c}\text { Mix } \\
\text { Proportion }\end{array}$ & 7 Days & 14 Days & 27 Days \\
\hline $\begin{array}{c}\text { Normal } \\
\text { concrete }\end{array}$ & 1.01 & 1.74 & 2.52 \\
\hline $\mathrm{BC} 1$ & 2.18 & 2.48 & 3.15 \\
\hline $\mathrm{BC} 2$ & 2.65 & 2.87 & 3.64 \\
\hline $\mathrm{BC} 3$ & 2.40 & 2.56 & 3.29 \\
\hline
\end{tabular}

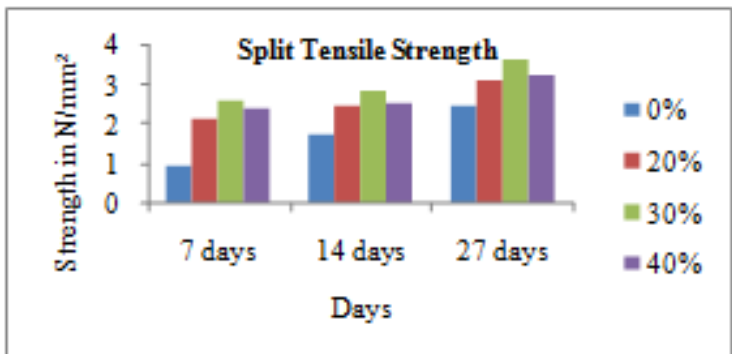

Figure 2: Split Tensile Strength

\subsection{Flexural Strength}

For each of the different dosages, three prisms with the dimensions of $150 \times 150 \times 500 \mathrm{~mm}$ were prepared. A vibrator was used for compaction of concrete in prisms. All prisms were demoulded after one day and immersed in the curing tank for a period of 28 days to assure sufficient curing. After 28 days, each prism was tested using the loading test setup. The flexural strengths achieved are $5.30 \mathrm{~N} / \mathrm{mm} 2,5.79$ $\mathrm{N} / \mathrm{mm} 2,6.55 \mathrm{~N} / \mathrm{mm} 2$ and $5.98 \mathrm{~N} / \mathrm{mm} 2$ at $0 \%, 20 \%, 30 \%$ and $40 \%$ for GGBS concrete respectively for M30 grade concrete. The report shows that the strength gave good performance for $30 \%$ replacement which is more than normal concrete.
Table 10: Flexural strength Results

\begin{tabular}{|c|c|}
\hline Mix Proportion & 28 days \\
\hline Normal Concrete & 5.30 \\
\hline BC1 & 5.79 \\
\hline BC2 & 6.55 \\
\hline BC3 & 5.98 \\
\hline
\end{tabular}

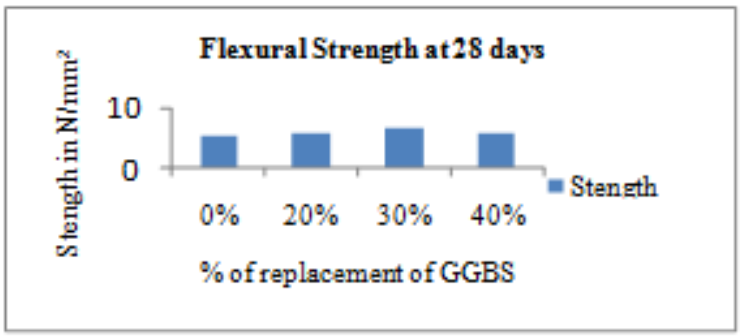

Figure 3: Flexural Strength

\section{Conclusions}

1. From the mechanical properties, the optimum replacement by GGBS was found to be $30 \%$ and beyond $30 \%$ all the strength values decreased when compared to normal concrete.

2. It was found that as percentage of GGBS increases, the workability of GGBS increases and the strength gets reduced. In order to increase the strength, cement is replaced by combination of GGBS and RHA.

3. GGBS and steel fibers can be used in concrete as suitable replacement of cement to make concrete strong in both compression and tension and also the use of RHA makes the concrete lighter.

4. Higher strength development is due to filler effects of GGBS, fineness of RHA and properties of steel fiber.

5. Replacing the cement with GGBS keeping RHA and steel fibers is one of the good solutions available to the problem of environmental impacts.

\section{References}

[1] Vinayak Awasare and Prof. M. V. Nagendra., "Analysis of Strength Characteristics of GGBS Concrete", International Journal of Advanced Engineering Technology, Vol. V/Issue II/April-June, 2014.

[2] Sonali K. Gadpalliwar and R. S. Deotale., "To Study the Partial Replacement of Cement by GGBS \& RHA and Natural Sand by Quarry Sand In Concrete", IOSR Journal of Mechanical and Civil Engineering (IOSR-JMCE) Volume 11, Issue 2 Ver. II (Mar- Apr. 2014)

[3] Neeraja.D. "Experimental Investigations on Strength Characteristics of Steel Fiber Reinforced Concrete", International Journal of Scientific \& Engineering Research Volume 4, Issue 2, February-2013.

[4] Mr. Nikhil A. Gadge and Prof. S. S. Vidhale., "Mix Design of Fiber Reinforced Concrete (FRC) Using Slag \& Steel Fiber", International Journal of Modern Engineering Research (IJMER), Vol. 3, Issue. 6, Nov - Dec. 2013

[5] M. Adams Joe., "An Experimental Investigation on the Effect of GGBS \& Steel Fiber in High Performance Concrete", International Journal of Computational Engineering Research, Vol 04,Issue, 4, April 2014 